\title{
A protein in rat prostatic chromatin interacting with androgen regulated gene
}

\author{
XU Youhai, Rong CHANG, Qiubao SONG and Shiming \\ CHANG \\ Shanghai Institute of Cell Biology, Academia Sinica
}

\begin{abstract}
$2 M \mathrm{NaCl}$-insoluble fraction of rat ventral prostate chromatin (residual proteins) contain proteins able to interact specifically with androgen-receptor complex and is, therefore, a part of the acceptor complex. Among residual proteins, a $97 \mathrm{KDa}$ protein has been found which binds significantly to a genomic fiagment containing an androgen-regulated gene coding for a $22 \mathrm{KDa}$ protein. The biological significance of this binding in androgen action need to be further studied.

A mini-plasmid clone containing $22 \mathrm{KDa}$ protein coding sequence was cloned into Charon $4 \mathrm{~A}$ genomic library from which a $5.7 \mathrm{~Kb}$ genomic fragment was isolated, identified by hybridization with a 5' and a 3' cDNA probes, and shown to contain the 5' flanking sequence.Restriction enzyme treatment of this fragment yielded a $4.7 \mathrm{~Kb}$ restriction fragment representing the 5' upstream region and a $1.0 \mathrm{~Kb}$ containing part of the coding sequence. Deletion studies indicated that the $97 \mathrm{KDa}$ protein bound only to a subclone of about $300 \mathrm{bp}$ segment. Furthermore, gel shifting experiment supported its DNA-protein binding.
\end{abstract}

Key words: rat prostatic chromatin, 97KDa residual protein, androgen regulated gene sequences, androgen receptor binding sites.

\section{INTRODUCTION}

Androgens, like other steroid hormones, act on responsive cells by the regulation of specific gene expression. As we have known to date, there are three positively-regulated proteins(a $51 \mathrm{KDa} \mathrm{PBP}$ [1], a $22 \mathrm{KDa}$ glycoprotein [2] and a 34 KDa SBP) [3] and a negatively-regulated protein(29 KDa) [4]. Additionally, the 
Chromatin protein interacting with androgen regulated gene

expression of two other proteins $(13.5 \mathrm{KDa}$ and $9.3 \mathrm{KDa})$ is also regulated by androgens [5]. Similar to other steroid hormones, the mechanism of androgen action on gene expression in prostate may be closely associated with an androgen-induced change in chromatin structures which may result in a change in transcription patterns [6]. It indicated that the interacting chromatin components were important in androgen action. Foekens demonstrated that both DNA and proteins may participate in the binding of steroid-receptor to chromatin [7].

In addition to DNA, protein acceptor sites of chromatin have been reported in many laboratories and classified into two kinds: (1)salt-soluble acceptor, including $0.4 \mathrm{~mol} / \mathrm{L}$ salt-soluble acidic and $2 \mathrm{~mol} / \mathrm{L}$ salt-soluble basic acceptors[8], and (2) salt-insoluble acceptors[9-10]. Previous studies indicated that salt-insoluble chromatin components showed an androgen- and tissue-specificity, a DNAdependent binding to steroid-receptor complexes and an enrichment of androgenregulated sequences [11] Therefore, an interesting question is how DNA and residual proteins relate to each other in the tripartite interactions among androgens, receptor and acceptor in androgen action.

In this work, we reported an interaction of chromatin components, residual chromatin, fractionated by salt, with a DNA sequence coding for an androgenregulated $22 \mathrm{KDa}$ protein. In addition, the deletion studies indicated that the 97 KDa chromatin protein bound to a $0.3 \mathrm{~kb}$ upstream segment of the androgenregulated $22 \mathrm{KDa}$ probe in gene. The affinity binding was also supported by gel shifting experiment. Finally, the possible significance of the interaction between residual protein and 5' upstream DNA sequence has been discussed.

\section{MATERIALS AND METHODS}

\section{Animals and materials}

Male Sprague-Dawly rats, weighing about 300g, were bilaterally orchidectomized under ether anesthesia via scrotal route. Rats castrated for 2 days were used as androgen withdrawn animals. All biochemicals were of analytical grade (Sigma). [ $\left.a_{-}{ }^{32} \mathrm{P}\right] \mathrm{dNTPs}, 3000 \mathrm{ci} / \mathrm{mmol}$, were form Amersham. Restriction endonucleases and additional enzymes were purchased from BRL or Boehringer.

\section{Libraries and vectors}

Rat prostate cDNA lgt10 library was purchased from Clontech. Rat genomic DNA Charon 4A library was provided by Dr. Takashi Sugimura. Mini-plasmid $\pi$ AN7 and E. coli MC $1061 \mathrm{r}-\mathrm{m}+$ su- strain were gifts from Dr. Michael Garrick. E. coli NK 5486(1ac Zam)was taken from Dr. Edward Morgan. Host cells HB101 and JM 83 were provided by late Professor Li Weng-yu.

\section{Preparation and solubilization of residual chromatin}

Nuclei were isolated from rat ventral prostates according to the procedure of Blobel \& Potter(1966) [12.] The nuclei were used for the isolation of chromatin as described by Wang(1978)[13]. The solubilization of residual chromatin was performed following Teng et al. (1971)[14].

\section{Screening genomic library}

A cDNA fragment, coding for a $22 \mathrm{KDa}$ glycoprotein regulated by androgen[2], was isolated from pBR322cDNA-78, cloned into mini- plasmid $\pi \mathrm{AN} 7$, then used to screen the corresponding genomic fragment 
from lambda Charon 4A-rat liver genomic library by reciprocal recombination in host cell E. coli MC 1061 $\mathrm{r}-\mathrm{m}+\mathrm{su}-[15]$.

\section{Gross mapping of genomic fragment}

A physical map of $\lambda$ DNA-78 was deduced from the data of both partial digestion and Southern hybridization. $\lambda$ DNA-78 was labeled with $\left[a_{-}{ }^{32} \mathrm{P}\right] \mathrm{dGTP}$ and Klenow fragment [16], partially digested by restriction endonucleases and analysed on $0.3 \%$ agarose gel electrophoresis[17]. The cold DNA sample digested with the same restriction endonucleases and hybridized with either a 3 ' or a 5 ' probe.

\section{Subcloning genomic fragments}

A $5.7 \mathrm{~kb}$ EcoR I fragment and its restriction digests, containing sequence homologous to 5 ' cDNA, were subcloned into vectors pUC 18 or 19, individually. The subcloned fragments were used as probes in the binding experiments of residual chromatin.

\section{Filter binding of residual chromatin to genomic fragments}

DNA fragments were end-labeled by the procedure of O'Farrell et al[18], and the specific activity of ${ }^{32} \mathrm{P}-$ DNA was $10^{7} \mathrm{cpm} / \mu \mathrm{g}$. The binding experiments of residual chromatin to end-labeled DNAs were performed according to Riggs et al. [19].Briefly, $0.25 \mathrm{ml}$ reaction mixture contained $1 \mathrm{ng}\left[a_{-}{ }^{32} \mathrm{P}\right] \mathrm{DNA}\left(10^{4} \mathrm{cpm}\right), 10-400$ ng protein, $10 \mathrm{mmol} / \mathrm{L}$ Tris-HCl (pH7.4), 10mmol/L MgAc2, 10mmol/L KCl, 0.1mmol/L EDTA, 0.1 $\mathrm{mmol} / \mathrm{L} \mathrm{DTT}, 5 \% \mathrm{DMSO}$ and $0.1 \% \mathrm{BSA}$. After incubation at $25^{\circ} \mathrm{C}$ for $30 \mathrm{~min}$, the reaction mixture was chilled on ice and filtered through S\&S BA 85 nitrocellulose (N. C.)membrane (pre-soaked in binding buffer minus DDT and BSA)under vacuum. Identical reactions but without protein were run in parallel to serve as controls. Non-bound filtrate was also collected for agarose gel electrophoresis to corroborate the binding results. Cold $5.7 \mathrm{~kb}$ DNA, salmon sperm DNA and calf thymus DNA (1-200ng) were used as a competitor DNA for determining the specificity of the binding reaction.

\section{Western blot and binding of residual chromatin}

Residual proteins were fractionated on $10 \%$ SDS-PAGE[20]. The proteins were electro-transfered onto nitrocellulose (N.C.) membranes at $6-8 \mathrm{~V} / \mathrm{cm}$ and $4^{\circ} \mathrm{C}$ overnight in a transferring buffer $(20 \mathrm{mmol} / \mathrm{L}$ Trisbase, $150 \mathrm{mmol} / \mathrm{L}$ glycine and $20 \%$ methanol)[21]. The N. C. membranes were pre-treated in binding buffer (10 mmol/L Tris-HCl/pH 7.0, lx Denhardt's, $50 \mathrm{mmol} / \mathrm{L} \mathrm{NaCl}$ and $50 \mu \mathrm{g} / \mathrm{ml}$ sperm DNA) with gentle shaking at $20^{\circ} \mathrm{C}$. After $30 \mathrm{~min}, 10^{5} \mathrm{cpm} \operatorname{DNA}(0.2 \mu \mathrm{g})$ fragments were added into barfer and incubated for additional 2 hours. Then the membranes were washed in the same buffer 4 times, for 15 min each time. The membranes were dried in air and exposed to X-ray film at $-70^{\circ} \mathrm{C}$.

\section{Gel Shifting}

$5 \mu \mathrm{g}$ residual proteins were mixed with $4 \mathrm{ng}$ DNA $\left(10^{5} \mathrm{cpm}\right)$ in a $20 \mu \mathrm{l}$ buffer $(10 \mathrm{mmol} / \mathrm{L}$ Tris $\mathrm{HCl} / \mathrm{pH} 7.5$, $60 \mathrm{mmol} / \mathrm{L} \mathrm{KCl}, 7.5 \%$ glycerl, o0.1 mmol/L EDTA, $0.75 \mathrm{mmol} / \mathrm{L}$ DTT, $5 \mathrm{mmol} / \mathrm{L} \mathrm{MgCl}_{2}$ and $0.5 \mu \mathrm{g} \mathrm{pBR322}$ Hinfi) at $20^{\circ} \mathrm{C}$ for $\mathrm{lh}$ and loaded immediately onto 6\% PAGE-0.25xTBE[22]. Gel electrophoresis was performed in TBE at 100 volt and $4^{\circ} \mathrm{C}$ for $3-4$ hours. The gel was exposed to X-ray film after dried in Gel-Dryer.

\section{RESULTS}

\section{Screening and mapping of genomic fragments}

A 300 bp cDNA fragment(from pBR322 clone-78)has been identified to code for a $22 \mathrm{KDa}$ glycoprotein in the cytosol of rat prostate in our previous work. The cDNA fragment was inserted into PstI site of mini-plasmd $\pi$ AN7, then the hybrid $\pi$ AN7 was integrated into phage chromosome of lambda Charon 4A-rat liver genomic library by reciprocal recombination in SupF cell, MC 1061r-m + su-. The selected 
Chromatin protein interacting with androgen regulated gene
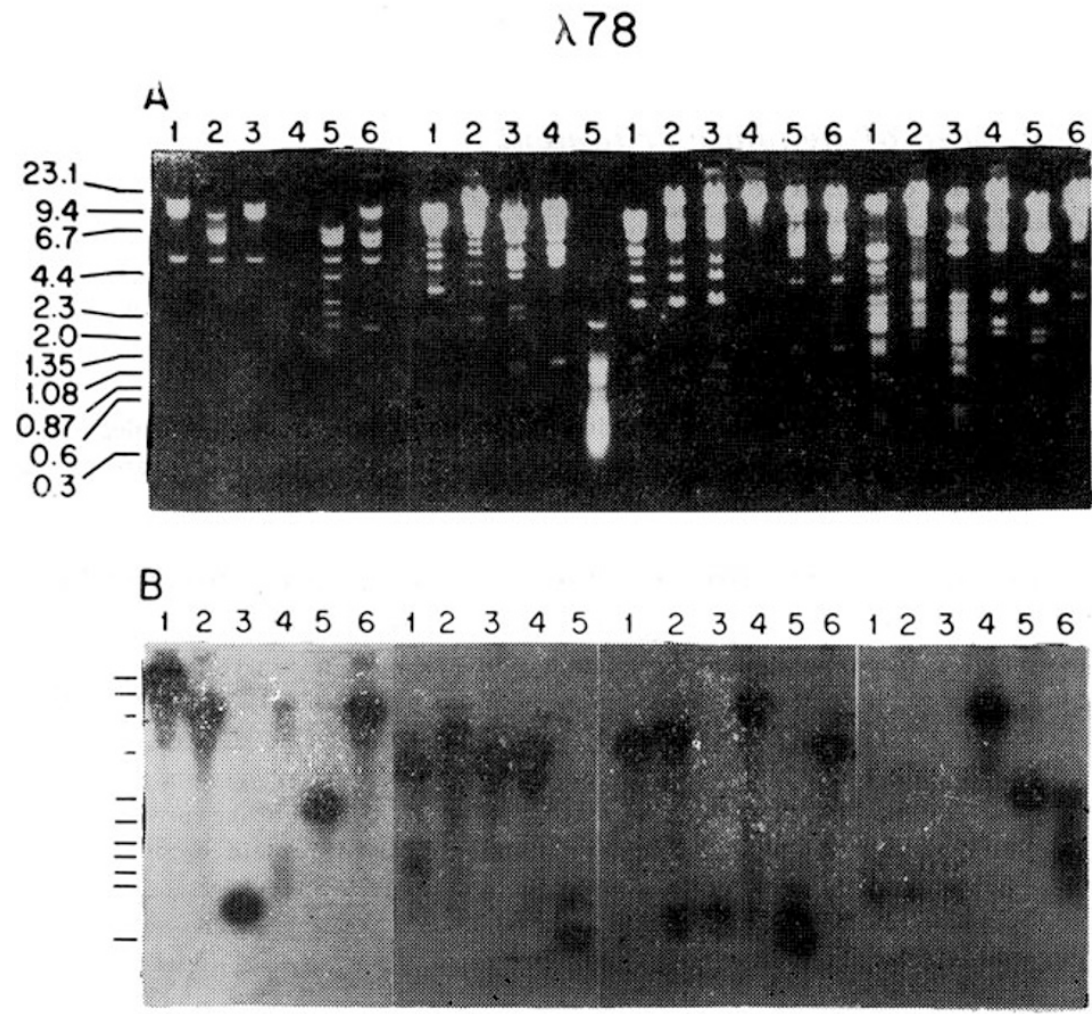

C 12345612345123456123456

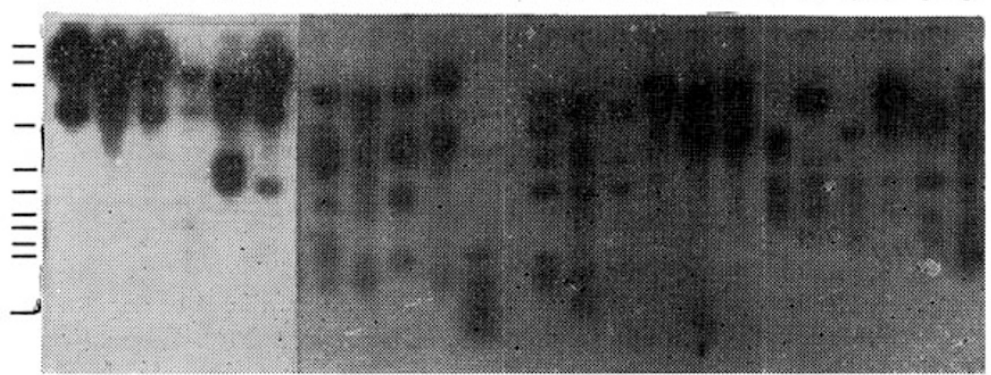

Fig. 1 Southern blot hybridization of restriction fragments of lambda genomic DNA78 with two cDNA probes. The genomic fragment lambda DNA78 was digested with combinations of various restriction endonucleases. The digests were subjected to $0.7 \%$ agarose gel electrophoresis(A), and Southern blot hybridized with $\left[{ }^{32} \mathrm{P}\right]$ pBRcDNA78 probe(B)and $\left[{ }^{32} \mathrm{p}\right]$-lambda $\mathrm{gt}^{10} \mathrm{cDNA} 78$ probe $(\mathrm{C})$. The various restriction digestions are shown in four frames reading from left to right. First frame: lane 1, EcoRI; lane 2, EcoRI+SalI; lane 3, EcoRI+XbaI; lane 4, EcoRI + BamHI; lane 5, EcoRI + SphI; and lane 6, EcoRI + SmaI. Second frame. lane 1, EeoRI + KpnI; lane 2, KpnI; lane 3, KpnI + SmaI; lane 4, SmaI; and lane 5, HaeIII. Third frame: lane 1, SmaI+BamHI; lane 2, BamHI; lane 3, BamHI+XbaI; lane 4, XbaI; lane 5, XbaI+SalI; and lane 6, SalI. Fourth frame: lane I, SalI+PstI; lane 2, PstI; lane 3, PstI+SphI; lane 4, SphI; lane 5, SphI+HindIII; and lane 6, HindIII. Input of both $\left[{ }^{32} \mathrm{P}\right] \mathrm{cDNA}$ probes was $5 \times 106 \mathrm{cpm}$; film exposure was for $12 \mathrm{~h}$. DNA size markers shown at left were HindIIl digest of lambda DNA and HaeIII digest of $\phi$ X174 DNA. 
lambda DNA clones with a homologous sequence to cDNA-78 were identified by genetic test and dot hybridization(data not shown).

$\lambda$ DNA-78 prepared from the positive plaques was end-labeled with $\left[a_{-}{ }^{32} \mathrm{P}\right]$ dGTP and digested by various endonucleases to locate the restriction sites. The same digested $\lambda$ DNA-78 were Southern blot hybridized to pBRcDNA-78 and $\lambda$ gt 10 cDNA-78 (a 5' cDNA probe, data not shown) for identificatin of both 3' and 5' regions of the genomic fragment. Of the restricted samples, a $5.7 \mathrm{~kb}$ fragment from a complete EcoRI digestion (Fig. 1-C, left panel 1)was shown to give strong hybridization to $\lambda$ gt10 cDNA-78. This fragment was subcloned into pUCl9 and used in chromatin binding experiments described in the following section. From these results, a gross restriction map of the genomic fragment was deduced, as shown in Fig. 2-A. Also, a detailed information on cleavage sites was obtained (Fig. 2-B). There were a BstEII site on the 4400th bp and a ClaI site on the 4700th bp from 5' end of the fragment. The $5^{\prime}$ or $3^{\prime}$ end of $5.7 \mathrm{~kb}$ fragment was orientated by force cloning EcoRI-ClaI fragment $(4.7 \mathrm{~kb})$ into EcoRI-AccI sites of pUC18 and ClaIEcoRI fragment (1.0kb)in\%o AccI-EcoRI sites of pUC19, respectively, as shown in Figure 3.
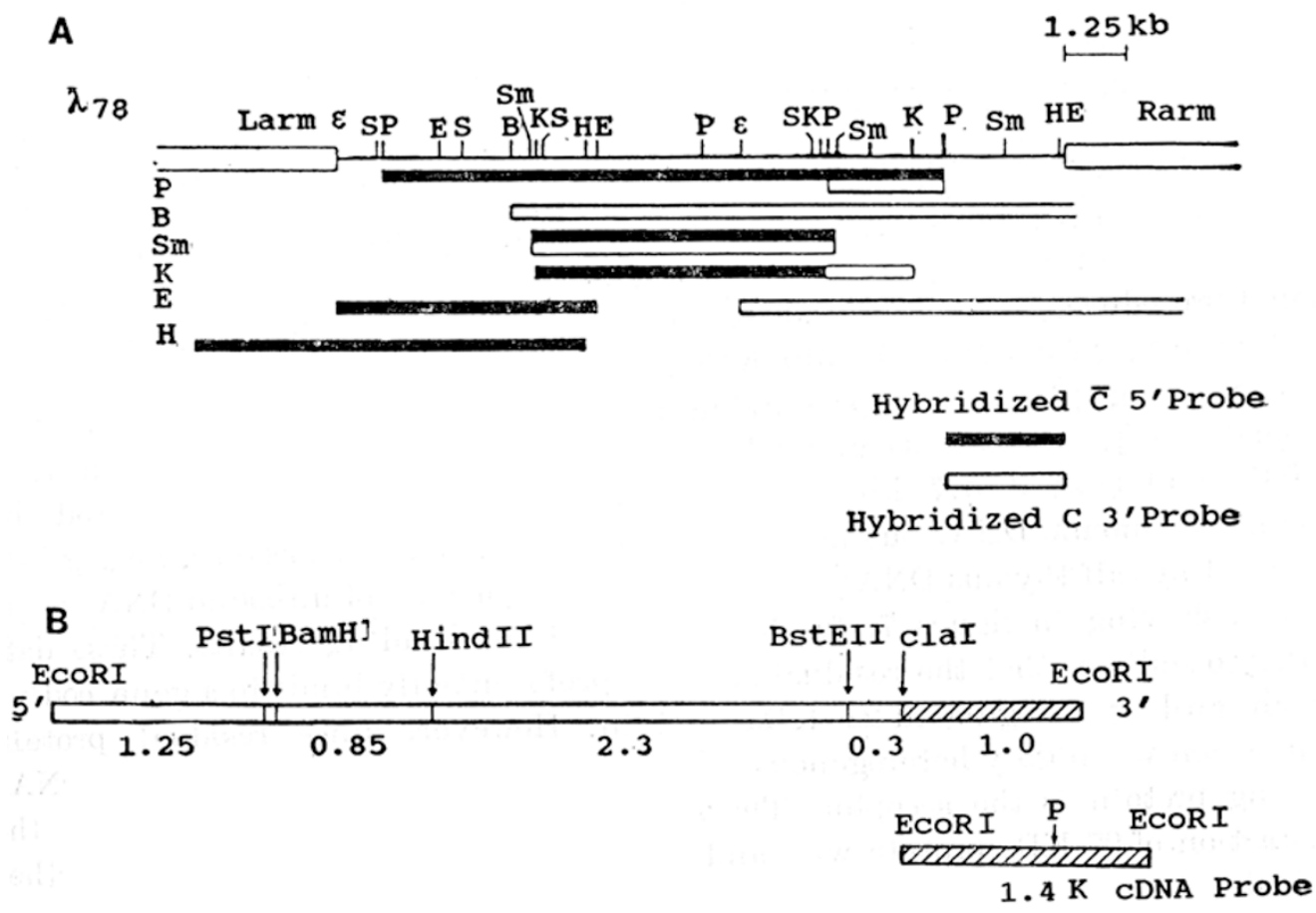

Fig. 2 Restriction map of lambda genomic DNA-78 (A)and 5.7kb genomic fragment (B).

\section{Binding of residual proteins to The genomic fragment}

The residual chromatin, which contains $40 \%$ of nuclear androgen binding sites[11], is refractory to solubilization; its DNA is also resistant to dissociation. We have finally succeeded in solubilizing residual proteins from rat prostate by 

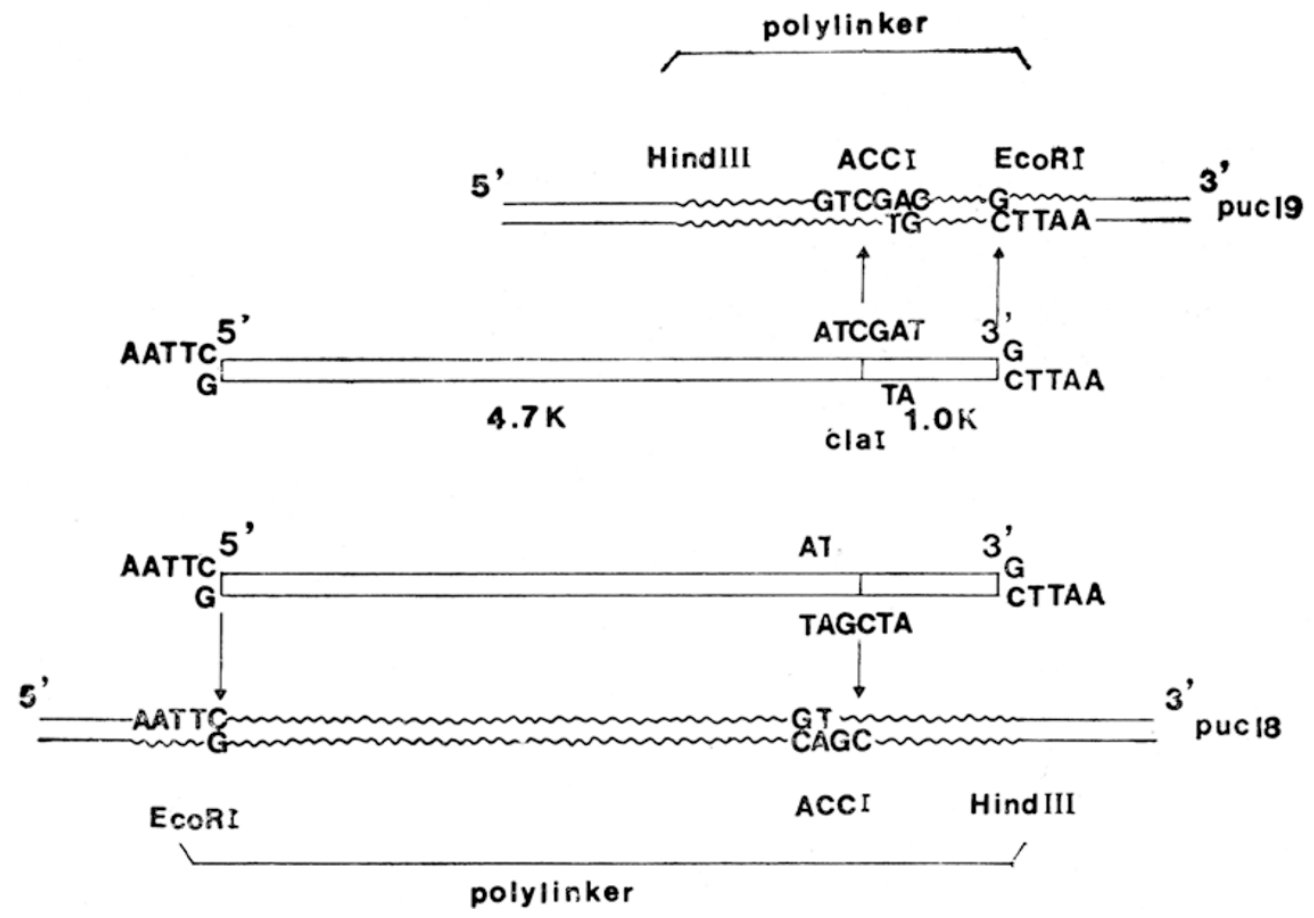

Fig. 3 The force-cloning of $5.7 \mathrm{~kb}$ genomic fragment. The $5.7 \mathrm{~kb}$ genomic fragment was digested by $\mathrm{ClaI}$ and the resulted two segments_- $4.7 \mathrm{~kb} \quad$ EcoRI—ClaI and $1.0 \mathrm{~kb}$ ClaI-EcoRI were subcloned into EcoRi-AccI sites of pUCI8 and AccI-EcoRI sites of pUCI9, respectively.

phenol procedure. The solubilized residual protein exhibited heterogeneity with species ranging from MW $17-310 \mathrm{KDa}$ (Fig. 4). The average yield was $5-7 \mu \mathrm{g}$ protein per g prostate, representing about $30 \%$ of protein in the residual chromatin [11]. As can be seen, residual protein showed $60 \%$ saturation binding to $\left[a-{ }^{32} \mathrm{P}\right]$ end-labeled $5.7 \mathrm{~kb}$ DNA (Fig. 5). This binding was competed by unlabeled genomic DNA, but not by salmon sperm DNA and was only negligiblly competed by calf thymus DNA (Fig. 6). Gel electrophoresis of unbound DNA in the filtrate, showing in figure 7 , further supporbed the binding results. These data appear to indicate that the residual acceptor preferentially binds to a gene coding for an androgen-regulated $22 \mathrm{KDa}$ protein. However, since residual protein preparation was highly heterogenous, it can not be ascertained whether the DNAbinding protein is the acceptor. The specific binding DNA sequences and the interaction of $97 \mathrm{KDa}$ protein with androgen-receptor complex need to be further studied.

As shown in Fig. 8, a $97 \mathrm{KDa}$ protein was bound to $\left[{ }^{32} \mathrm{P}\right] \mathrm{dATP}$ labeled $5.7 \mathrm{~kb}$ genomic fragment after PAGE fractionation and N.C. membrane transfer. The control DNAs, sperm DNA and $\Upsilon$-globin promoter sequence (from Dr. Zhu, J. D.) showed a negative result These results further supported that the binding of 97 $\mathrm{KDa}$ protein is gene specific. Comparing with BSA, the binding of residual proteins to genomic fragment was 3 -fold higher at the level of saturation (Fig. 9). Among 


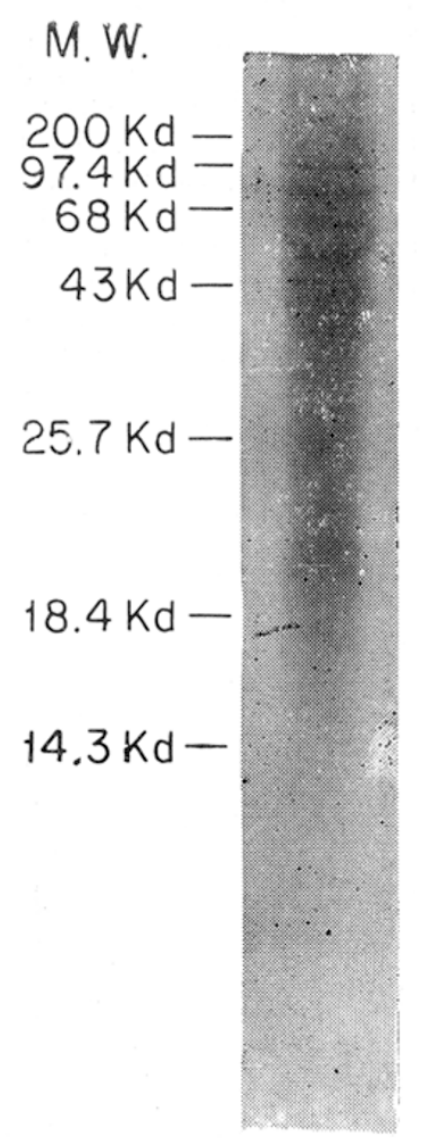

Fig. 4 Polyacrylamide gel electrophoresis of solubilized residual chromatin protein. About $100 \mu \mathrm{g}$ of solubilized residual chromatin protein was precipitated with 5\% TCA; the precipitate was washed with $100 \%$ ethanol, dissolved in sample buffer, and subjected to $12.5 \%$ polyacrylamide gel electrophoresis. Markers in kilodalton shown on the left from top to bottom: myosin heavy chain (200), phosphorylase b (97.4), BSA(68), ovalbumin(43), chymotrypsinogen (25.7), lactoglobulin (18.4) and lysozyme (14.3).

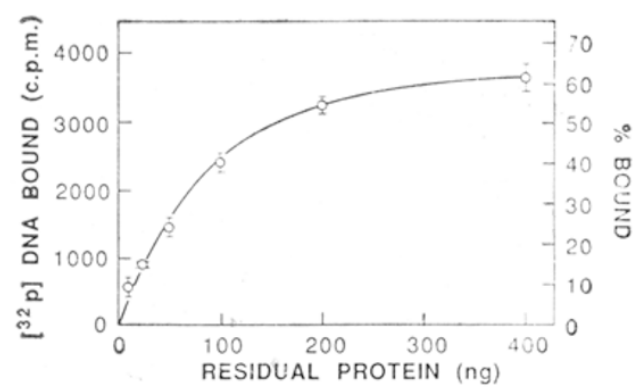

Fig. 5 Binding of residual protein to $5.7 \mathrm{~kb}$ genomic fragment containing $22 \mathrm{~Kb}$ glycoprotein gene sequences. One ng of $3^{\prime}$ end-labeled $\left[{ }^{32} \mathrm{P}\right]$ genomic fragment $5.7 \mathrm{~kb}$ EcoRI fragment) was incubated with various amounts of the residual protein as indicated at $25^{\circ} \mathrm{C}$ for 30 min. After incubation, each sample, in triplicates, was filtered through a nitrocellulose BA85 filter and both filter (bound DNA) and filtrate (unbound DNA) were counted in toluene scintillation cocktail. The bound radioactivity counts were subtracted by background counts (control assay without protein) and plotted against protein concentration. Vertical bars represent standard error.

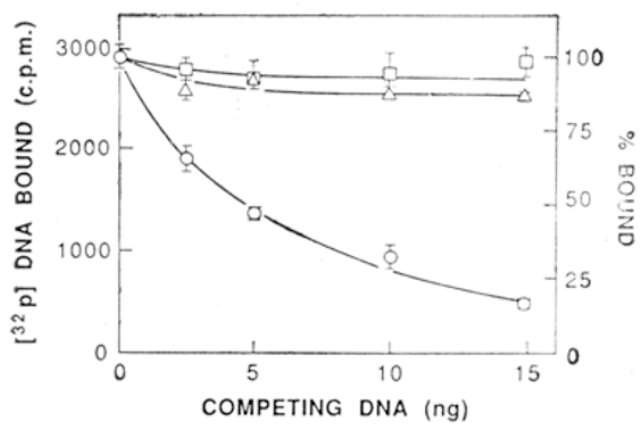

Fig. 6 Competition of residual protein binding to genomic DNA by homologous and heterologous DNA. One ng of $\left[{ }^{32} \mathrm{P}\right]$-end labeled $5.7 \mathrm{~kb}$ genomic DNA $\left(10^{4} \mathrm{cpm}\right)$ was incubated with $200 \mathrm{ng}$ of residual protein at $25^{\circ} \mathrm{C}$ for $30 \mathrm{~min}$ in the presence or absence of unlabeled genomic DNA $(\bigcirc)$, calf thymus $\operatorname{DNA}(\triangle)$ and salmon sperm DNA( $\square)$. Experimental conditions and processing of samples were the same as in Fig. 3. The amounts of competitor DNAs used in the assays were as shown. 


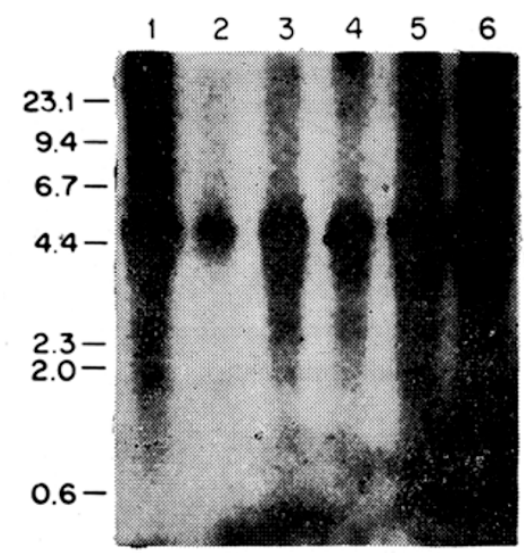

Fig. 7 Specificity of residual protein binding to genomic DNA. The filtrates (unbound DNA) obtained from the experiment shown in Fig. 5 were subjected to $0.7 \%$ agarose gel electrophoresis and the gel was exposed to x-ray film for $12 \mathrm{~h}$. The electrophoretic pattern indicates the relative amounts of the unbound DNA in the presence of competitor genomic DNA. Lane 1, no protein in the assay; lanes 2 to 6 , binding in the presence of $0,2.5,5.0$, 10 and $15 \mathrm{ng}$ of unlabeled Competitor genomic DNA.

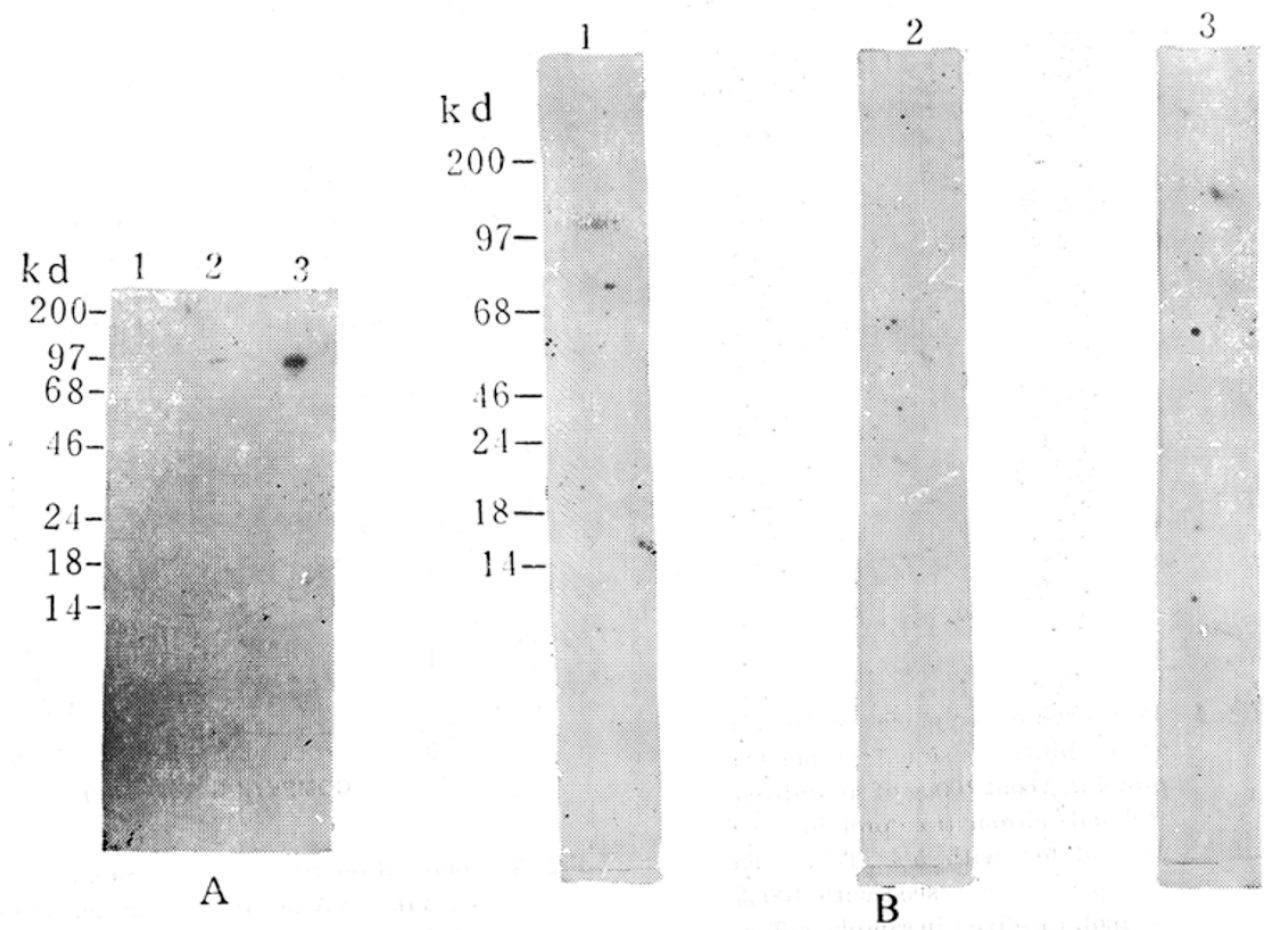

Fig. 8 Residual protein binding to androgen- dependent genomic fragment.

(A.) Residual ploteins were separated in $10 \%$ SDS--PAGE, electro-transferred onto NC filter and incubated with a $\left(a-^{32} \mathrm{P}\right)$ end-labeled $5.7 \mathrm{~kb}$ fragment in binding $\mathrm{BF}\left(2 \times 10^{5} \mathrm{cpm} / \mathrm{ml}\right)$. Lane $1,2 \mu \mathrm{g}$ of $0.1 \mathrm{M} \mathrm{NaCl}$ extract as a control. Lanes 2 and 3, 2 or $4 \mu \mathrm{g}$ of residual proteins, respectively. The molecular markers were shown on the left.

(B) Residual proteins were incubated with different probes: Lane $1,\left(a-{ }^{32} \mathrm{P}\right)$ $5.7 \mathrm{~kb}$ fragment, lane 2, salmon sperm DNA, and lane $3, \Upsilon$-globin DNA, each $2-3 \times 10^{5} \mathrm{cpm} / \mathrm{ml}$ in binding $\mathrm{BF}$. 
A

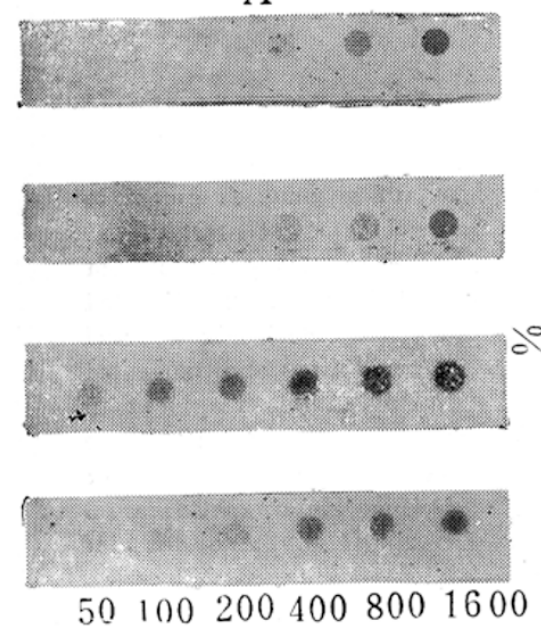

B

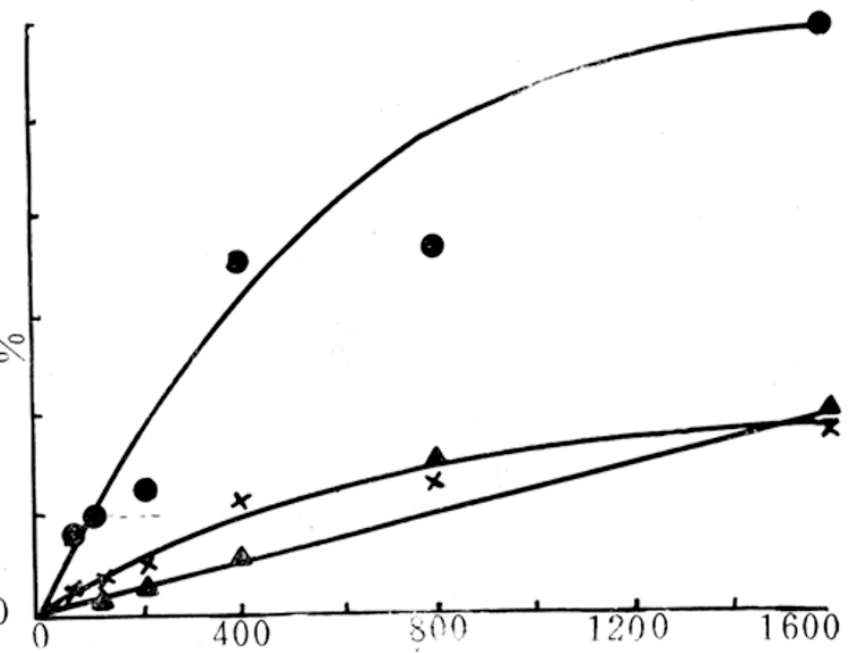

Fig. 9 The binding of residual chromatin of rat prostate to androgen-dependent genomic fragment. (A) Residual proteins (top)were blotted on to N. C. fitter by the amounts as showed and stained with Amido Black B 10. $0.1 M \mathrm{NaCl}$ extract of chromatin was used as a control (bottom).

(B) ]Binding of $\left(\alpha_{-}{ }^{32} \mathrm{P}\right)$ end-labeled $5.7 \mathrm{~kb}$ genomic fragment to residual proteins after incubation in binding $\mathrm{BF}\left(2 \times 10^{5} \mathrm{cpm} / \mathrm{ml}\right)$. The curves represent the relative densities in dots in relation to the concentration of the amount of both proteins. - - - binding to residual proteins. $-\mathrm{X}-$, binding to control proteins. $-\mathbf{\Delta}-$, the amount of loaded proteins.

the several subcloned fragments of $5.7 \mathrm{~kb}$ genomic DNA, only BstEII-ClaI fragment $(0.3 \mathrm{~kb})$ bound to $97 \mathrm{KDa}$ protein (Fig. 10). The $0.3 \mathrm{~kb}$ fragment was located above ClaI site in 5' direction. On tho other hand, the binding of residual protein showed a tissue specificity in the further experiment. As shown in Fig. 11, the same androgen regulated genomic fragment bound only to residual protein from prostate(lanes 3 and 4), but not that from liver (lanes 7 and 8). However, both of low MW proteins in $2 M$-soluble fraction (probable histones)from prostate and liver bound to DNA fragment(lanes 1, 2, 5, and 6).

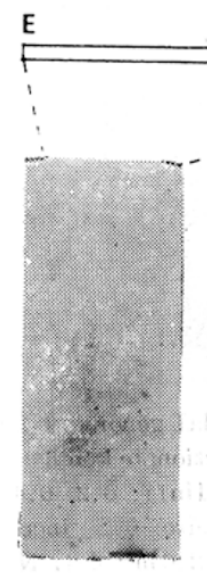

A

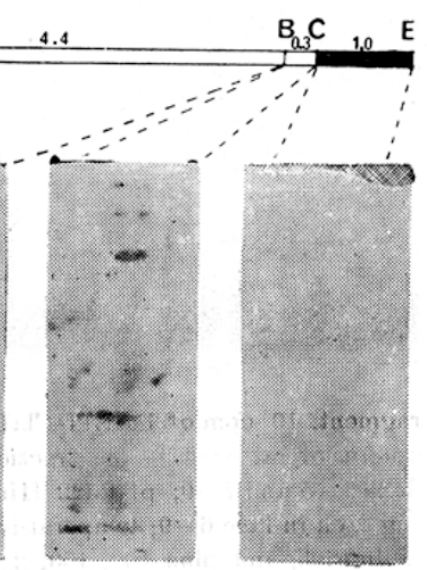

B
C
Fig. 10 The binding of chromatin proteins to BstEII-ClaI genomic fragment. After SDS-PAGE and N. C. membrane blotting, $3 \mu \mathrm{g}$ of residual proteins were bound to various segments of $5.7 \mathrm{~Kb}$ genomic fragment: (A) P-EcoRIBstEII, 4.4Kb; (B) P-BstEII-ClaI, $0.3 \mathrm{~Kb}$; and (C) P-ClaI-EcoRI, $1.0 \mathrm{~Kb}$. $\mathrm{X}$-ray was exposed for $16 \mathrm{~h}$. 
Chromatin protein interacting with androgen regulated gene

\section{$\begin{array}{llllllllll}1 & 2 & 3 & 4 & 5 & 6 & 7 & 8 & \text { MW }\end{array}$}

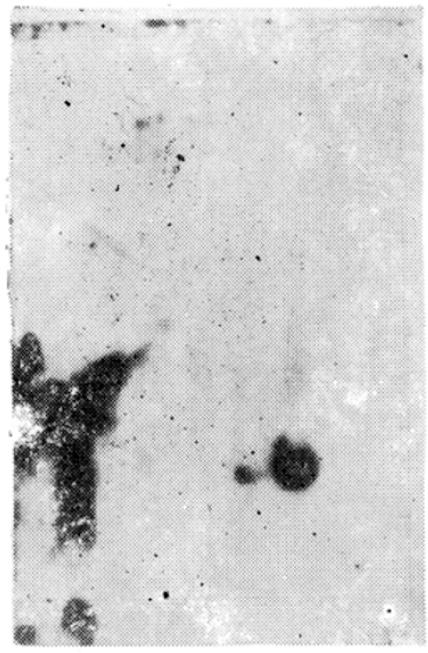

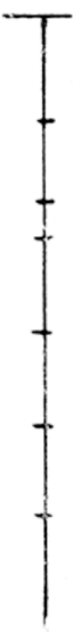

Fig. 11 The binding of genomic fragment to chromatin proteins of rat prostate and liver. $3 \mu \mathrm{g}$ of chromatin proteins from rat prostate or liver were fractionated $10 \%$ SDS-PAGE, electro-transferred onto N C. membranes and incubated with $\mathrm{P}-5.7 \mathrm{~Kb}$ genomic fragment in binding buffer. Lane 1 and 2: prostate salt-soluble chromatin; Lane 3 and 4 : prostate salt-insoluble chromatin; lane 5 and 6: Liver salt-soluble chromatin: lane 7 and 8: liver salt-insoluble chromatin. X-ray film was exposed for $24 \mathrm{~h}$.

The binding specificity has received some support from gel shifting experiments. Comparing with free protein sample, $0.3 \mathrm{~kb}$ genomic fragment migrated slower after incubating with the residual protein (Fig. 12). Furthermore, the raised $\mathrm{Na}^{+}$concentration (up to $200 \mathrm{mmol} / \mathrm{L}$ ) did not show any effect on the sample migration, which meant a tight binding of residual protein to the upstream region of a coding gene.

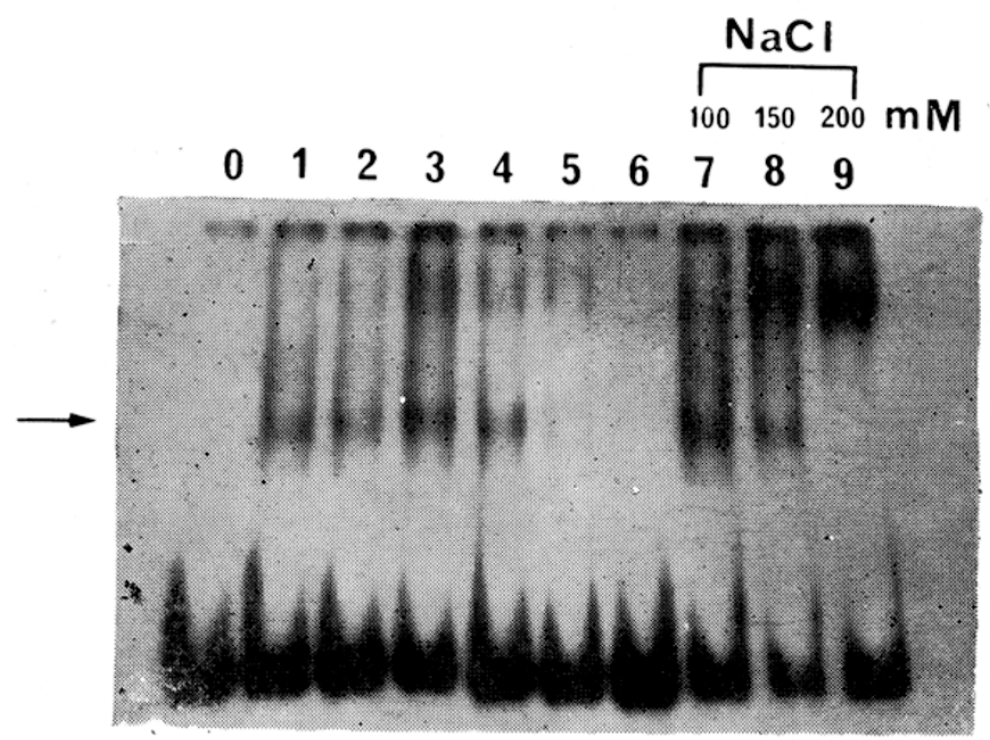

Fig. 12 Gel shifting of BstEII-ClaI genomic fragment. $10^{5} \mathrm{cpm}$ of BstEII-ClaI genomic fragment $(0.3 \mathrm{~Kb})$ was incubated with residual proteins of rat prostate and fractionated on $6 \%$ SDSPAGE. Residual proteins: $5 \mu \mathrm{g}$ each in lane $1-5$ and $7-9$; pBR322 HinfI: $0.2,0.4,0.6$, $0.8 \mu \mathrm{g}$ in lane $2-5$, respectively, and $1 \mu \mathrm{g}$ each in lane $6-9$; temperature: $0^{\circ} \mathrm{C}$; incubation time: $90 \mathrm{~min}$. Ionic strength: $60 \mathrm{mmol} / \mathrm{L}$ in each, and plus $100,150,200 \mathrm{mmol} / \mathrm{L} \mathrm{NaCl}$ in lane $7-9$, respectively. 


\section{DISCUSSION}

In this work, we have attempted to elucidate the nuclear events of androgen action in ventral prostate of rat. In androgen action the only known event preceding the activation of selective transcription is the alteration of prostate chromatin structure[23-24]. Correlation of the altered chromatin structure and transcription with androgen receptor binding sites (acceptors) would therefore be a logical approach to delineate nuclear events of androgen action. Our previous work on prostate active chromatin was carried out with such an attempt. The results suggasted that the changed chromatin conformation, androgen receptor binding sites (acceptors)and androgen specific DNA sequences are spatially arranged in a particular domain in response to androgen action [6].

The chromatin androgen binding sites, the acceptors, represent the important link between androgen receptor complex and activated transcription. Although recent evidence indicates preferential interaction of steroid receptors with enhancer-like elements of specific genes [25-27], there is ample documentation of multiple protein acceptors. We have, therefore, taken one of these acceptor fractions, the high salt-resistant residual chromatin, for approaching to this goal.

It has been already established that solubilized residual protein showed significant acceptor activity and that residual DNA, which means DNA in residual chromatin, was enriched in androgen-regulated sequences encoding the prostate binding protein[11]. To support that residual protein is directly related to androgen regulated sequences, we isolated a genomic fragment encoding the 22 KDa prtein by screening from a rat genomic library and used this fragment for protein binding experiments. Despite the heterogeneity of protein preparation, the results suggest strongly that residual protein binds specifically to androgen regulated gene sequences and support the involvement of proteins in the mediation of receptor activity.

In a further study, we found that a $97 \mathrm{KDa}$ protein may be responsible for the binding of residual chromatin to the genomic fragment. Also, gel shifting experiment demonstrated that a segment, located at about $300 \mathrm{bp}$ above ClaI site in the $5^{\prime}$ direction, bound to this $97 \mathrm{KDa}$ protein. Although we have not shown that the binding is sequence-specific, the data given here is suggestive for a correlation between androgen-receptor and regulatory sequence of a gene. Of course, we do not know whether this binding would lead to a conformational change in the bound region as in active chromatin which bound more androgen receptor [6], or would contribute only a small fraction to the androgen-specific gene transcription. To interpret the mechanism of androgen action, it is urgent to study the relationship of this $97 \mathrm{KDa}$ protein to a purified androgen-receptor complex and the effect of this binding on gene transcription in vivo or in vitro system. So far, the evidences had suggested that $97 \mathrm{KDa}$ protein may at least be a candidate for trans-acting protein which plays a role in androgen regulation of gene expression.

Androgen receptor is known to be DNA-binding and binds usually to a 
Chromatin protein interacting with androgen regulated gene

conservative sequence at the upstream promotor region. However, at the present time, $97 \mathrm{KDa}$ protein can not be correlated to either androgen-receptor bound DNA or androgen-regulated transcription. It may mean that DNA confers certain conformation to residual protein which is required for androgen receptor interaction. It is also possible that androgen-receptor complexes recognize only the DNA-protein configuration. Considering its high degree of specificity (tissueand steroid-specificity, and preferential binding to androgen regulated gene), residual protein may likely play an important role in gene expression, by interacting either directly or indirectly with androgen-receptor complexes. A more detail study on this purified residual protein and its relationship to both $5^{\prime}$ upstream sequence and androgen-receptor complex would throw some light to the mechanism of androgen action.

\section{ACKNOWLEDGEMENTS}

We thank Dr. Tung-yue Wang for his generous help and usefull adviees. This work was supported by a grant (3880442)from the National Science Foundation of China.

\section{REFERENCES}

[ 1] Heyns W, Immunochemical measurement of prostatic binding protein. FEBS Letters 1977; 81: 43—47.

[2] Chamberlin LL, Mpanias OD, Wang TY. Isolation, properties, and androgen regulation of a 20-KDA protein from rat ventral prostate. Biochemistry 1983; 22: 3072—3077.

[ 3 ] Liang T, Mezzetti G, Chen C, Liao S.Selective polyamine-binding proteins-Spermine binding by an androgen-sensitive phosphoprotein, Biochim Biophys Acta 1978; 542: 430—441.

[ 4 ] Satzman AG, Hiipakka RA, Chen C, Liao S. Androgen repression of the production of a 29-KDa protein and its mRNA in the rat ventral prostate, J Biol Chem 1987; 262:432—437.

[ 5 ] Xu YH, Mpanias OD, Wang TY. Identification of two cDNA clones coding for androgen-dependent polypepti es in rat ventral prostate. Biochem Biophys Res Comm 1983; 111: 624—629.

[6] Xu YH, Luo RS, Wang TY. Preferential binding of androgen to transcriptionally active chromatin in rat prostate. J Steroid Biochem 1987; 26: 647-652.

[7 ] Foekens JA, Rennie PS, Cheng H, Bruchovsky N. In situ crosslinking of androgen receptors to nuclear acceptor sites of rat prostate with formaldehyde. J Biol. Chem 1985; 260: 10093-10098.

[ 8 ] Tymoczko JL, Liao S. Retention of an androgen-protein complex by nuclear chromatin aggregates: heat-labile factors. Biochim. Biophys Acta 1971; 252: 607-611.

[ 9 ] Nyberg LM, Wang TY. The role of the androgen-binding nonhistone proteins in the transcription of prostatic chromatin. J Steroid Biochem 1976; 7: 267-273.

[10] Barrack ER, Coffey DS. The specific binding of estrogens and androgens to the nuclear matrix of sex hormone responsive tissues. J Biol Chem 1980; 255: 7265—7275.

[I1] Wang TY, Luo RS, Xu YH. Acceptor proteins of rat prostate residual chromatin. Biochemstry 1984; 23: $5326-5329$.

[12] Blobel G, Potter VR. Nuclei from rat liver: isolation method that combines purity with high yield. Science 1966: 154: 1662-1665.

[13] Wang TY. The role of nonhistone chromosomal proteins in the interaction of prostate chromatin with androgen receptor complex. Biochim Biophys Acta 1978; 518: 81—88.

[14] Teng CS, Teng CT, Allfrey VG. Studies of nuclear acidic proteins-evidence for their phosphorylation, tissue specificity, selective binding to DNA, and stimulatory effects on transcription. J. Biol. Chem. 1971; 246: 3597-3609,

[15] Maniatis T, Fritsch EF, Sambrook J. Molecular Cloning-A Laboratory Manual. Cold Spring Harbor Laboratory: 1982:353-362.

[16] Drouin J. Cloning of human mitochondrial DNA in Escherichia coli.J. Mol. Biol 1980; i40: 15—20. 
[17] Smith HO, Birnsteil ML. A simple method for DNA restriction site mapping. Nucleic Acids Res 1976; 3: 2387-2396.

[18] O' Farrell PH, Kutter E, Nakanishi M. A restriction map of the bacteriophage T4 genome, Mol Gen Genet 1980; 179: 421-435.

[19] Riggs AD, Suzuki H, Bourgeois S. Lac repressor- operator interaction, I. Equilibrium Studies. J. Mol. Biol 1970; 48: 67-83.

[20] Laemmli UK. Cleavage of structural proteins during the assembly of the head of bacteriophage T4. Nature 1970; 227: 680—685.

[21] Towbin H, Staehelin T, Gordon J. Electrophoretic transfer of proteins from polyacrylamide gels to nitrocellulose sheets: procedure and some applications. Proc Natl Acad Sci USA 1979; 76: $4350-4354$.

[22] Boulanger PA, L' Etoile ND, Berk AT. A DNA-binding domain of human transcription factor IIIC2. Nuclear Acids Res 1989; 17: 7761-7769.

[23] Mainwaring WIP, Jones DM. Influences of receptor complexes on the properties of prostate chromatin, including its transcription by RNA polynerase. J Steroid Biochem 1975; 6: 475-481.

[24] Loot RM, Hu AL, Wang TY. Structurally altered and transcriptionally activated rat prostate chromatin induced by androgen. Biochim Biophys Acta 1977; 477: 312-321.

[25] Payvar F, De Franco D, Firestone GL, et al. Sequence-specific binding of glucocorticoid receptor to MTV DNA at sites within and upstream of the transcribed region. Cell 1983; 35:381—392.

[26] Compton JG, Schrader WT, O' Malley BW. DNA sequence preference of the progesterone receptor. Proc Natl Acad Sci USA 1983; 80:16-20.

[27] Jost JP, Sledran M, Geiser M. Preferential binding of estrogen-receptor complex to a region containing the estrogen-dependent hypomethylation site preceding the chicken vitellogenin II gene. Proc atl Acad Sci USA 1984- 81: 429—433.

\section{Received 27-3-1990. Revised 5-5-1990. Accepted 22-6-1990.}

